\title{
Avaliação da produção de Biometano a partir de resíduos da plantação de soja e feijão
}

\author{
João Pedro B. Simionato*, Josimar Elerate, Telma T. Franco.
}

\section{Resumo}

Com o agravamento das condições climáticas devido ao efeito estufa, torna-se relevante a discussão de novos combustíveis de origem renovável. O Brasil, por ser um dos maiores produtores agrícolas do mundo, possui uma quantidade muito grande de resíduos agrícolas que podem ser utilizados na geração de energia e de novos combustíveis. Dessa forma, amostras de resíduos das plantações de soja e feijão foram estudados para a avaliação da produção de biometano. Com a composição elementar das amostras foi possível se estimar o potencial bioquímico teórico dos resíduos, encontrando-se 416,41 mL CH4/gSV para os resíduos de soja e 244,83 mL CH4/gSV para os resíduos de feijão. A metodologia utilizada na digestão anaeróbia foi a VDI4630. Dessa forma, a proporção de inóculo/substrato nos reatores foi 3 para 1. Além disso, foram preparados reatores apenas com o inóculo, visto que o inóculo possui uma taxa própria de produção, e com celulose microcristalina para comparação. A coleta dos gases foi realizada diariamente e a quantificação foi feita através do deslocamento de coluna de água. A composição dos gases foi determinada via cromatografia gasosa. Os resíduos de feijão produziram, ao final do experimento, $219,92 \mathrm{~mL}$ de $\mathrm{CH} 4 / \mathrm{gSV}$, enquanto que os resíduos de soja produziram 269,53 mL de CH4/gSV. Assim, pode-se dizer que os resíduos agrícolas de soja e feijão são viáveis para a produção de biogás. Além disso, os resultados poderiam ser melhores com a realização de um pré-tratamento.

\section{Palavras-chave:}

Biogás, Digestão Anaeróbia, resíduos agrícolas.

\section{Introdução}

Umas das fontes energias renováveis que vem ganhando grande importância no cenário mundial é a energia a partir de biomassa ou Bioenergia.

As condições de produção de biomassa e a grande disponibilidade de terras no Brasil são aspectos extremamente favoráveis quando se considera seu uso energético. Com isso, o estudo da transformação de biomassa em bioenergia e bioprodutos dão ao país a oportunidade de liderar o desenvolvimento tecnológico desse segmento.

Uma das formas de produção de energia pela Biomassa é a geração do Biogás, que ocorre pelo processo de Digestão Anaeróbia. Nesse processo, microrganismos degradam a matéria orgânica na ausência de oxigênio e produzem o Biogás, que pode ser usado em ciclos termodinâmicos para produção de energia ou como combustível.

Dessa forma, a proposta geral desta pesquisa visa avaliar o potencial de produção de biogás gerado a partir dos resíduos agrícolas das plantações de feijão e soja, duas grandes culturas produzidas no Brasil.

Além disso, para uma análise mais geral da produção de biogás no Brasil, a consulta à literatura serve de apoio para a construção de uma base de dados com diversas biomassas brasileiras para comparação.

\section{Resultados e Discussão}

O potencial teórico de biometano dos resíduos escolhidos foi estimado com base no modelo proposto por Buswell e Mueller (1952) e modificado, posteriormente, por Boyle (1976). Para os resíduos de feijão, foi obtido um valor teórico de $244,83 \mathrm{~mL} \mathrm{CH}_{4} / \mathrm{gSV}$. Para os resíduos de soja, o valor teórico do potencial de biometano de $416,41 \mathrm{~mL} \mathrm{CH}_{4} / \mathrm{gSV}$.

Para 0 estudo do potencial real, a metodologia empregada foi a VDI4630. Os reatores continham a proporção de inóculo/substrato 3 para 1 com relação aos sólidos voláteis e foram mantidos a $37^{\circ} \mathrm{C}$ durante os 41 dias de experimento. $O$ inóculo utilizado foi fornecido pela Usina São Martinho em 2018. Periodicamente foram realizadas análises cromatográficas para determinar a composição do biogás produzido na digestão anaeróbia. Assim, ao final do experimento, o valor experimental do potencial de biometano obtido para os resíduos de feijão foi de $219,92 \mathrm{~mL} \mathrm{CH} / \mathrm{gSV}$, próximo ao valor teórico estimado. Já para os resíduos de soja, o valor encontrado foi de $269,53 \mathrm{~mL} \mathrm{CH}_{4} / \mathrm{gSV}$.

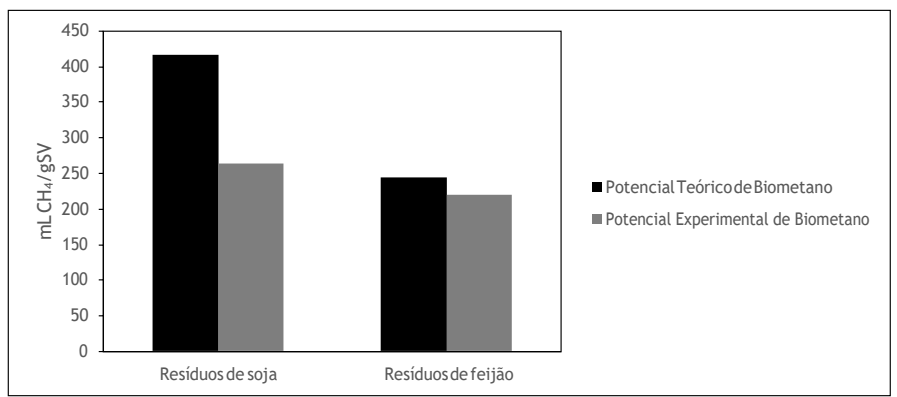

Figura 1. Comparação entre os potenciais teórico e experimental de biometano.

\section{Conclusões}

O estudo do biogás a partir das biomassas residuais foi satisfatório, principalmente para o caso dos resíduos de feijão, aproximadamente $10 \%$ de diferença com relação ao valor teórico estipulado. Entretanto, a produção de biometano dos resíduos de soja foi maior. Assim, podese afirmar que a produção de biometano a partir de biomassas residuais pode ser viável para a produção de biogás, bem como para energia elétrica.

\section{Agradecimentos}

À Prof. Dra. Telma Teixeira Franco pelo apoio.

À equipe pelo comprometimento no projeto.

Ao SAE pela concessão da bolsa e pela contribuição à pesquisa e ao desenvolvimento do país. 